\title{
Localized Calcium Signaling and the Control of Coupling at Cx36 Gap Junctions
}

\author{
Keith B. Moore, ${ }^{1}$ Cheryl K. Mitchell, ${ }^{1}$ Ya-Ping Lin, ${ }^{1}$ ○Yuan-Hao Lee, ${ }^{1}$ EEyad Shihabeddin, ${ }^{1,2}$ and \\ (D)John O'Brien ${ }^{1,2}$
}

https://doi.org/10.1523/ENEURO.0445-19.2020

${ }^{1}$ Richard S. Ruiz, M.D. Department of Ophthalmology and Visual Science, McGovern Medical School, The University of Texas Health Science Center at Houston, Houston, TX 77030 and ${ }^{2}$ The MD Anderson Cancer Center UTHealth Graduate School of Biomedical Sciences, Houston, TX 77030

\section{Visual Abstract}
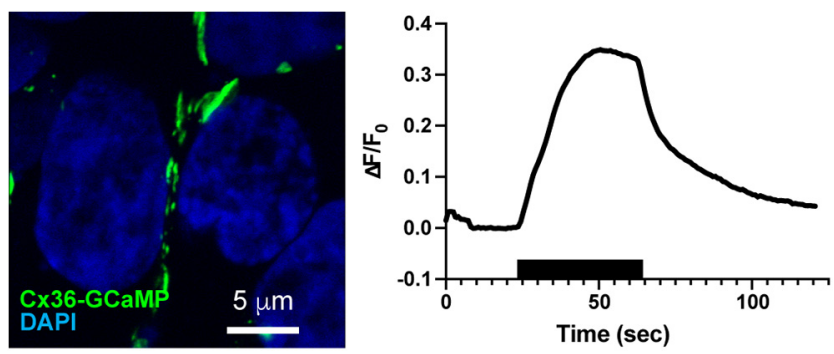

A variety of electrical synapses are capable of activity-dependent plasticity, including both activity-dependent potentiation and activity-dependent depression. In several types of neurons, activity-dependent electrical synapse plasticity depends on changes in the local $\mathrm{Ca}^{2+}$ environment. To enable study of local $\mathrm{Ca}^{2+}$ signaling that regulates plasticity, we developed a GCaMP $\mathrm{Ca}^{2+}$ biosensor fused to the electrical synapse protein Connexin 36 (Cx36). Cx36-GCaMP transfected into mammalian cell cultures formed gap junctions at cell-cell boundaries and supported Neurobiotin tracer coupling that was regulated by protein kinase A signaling in the same way as Cx36. Cx36-GCaMP gap junctions robustly reported local $\mathrm{Ca}^{2+}$ increases in response to addition of a $\mathrm{Ca}^{2+}$ ionophore with increases in fluorescence that recovered during washout. Recovery was strongly dependent on $\mathrm{Na}^{+}-\mathrm{Ca}^{2+}$ exchange activity. In cells transfected with NMDA receptor subunits, Cx36-GCaMP revealed transient and concentration-dependent increases in local $\mathrm{Ca}^{2+}$ on brief application of glutamate. In HeLa cells, glutamate application increased Cx36-GCaMP tracer coupling through a mechanism that depended in part on $\mathrm{Ca}^{2+}$, calmodulin-dependent protein kinase II (CaMKII) activity. This potentiation of coupling

\section{Significance Statement}

We have developed a Connexin 36 (Cx36)-GCaMP3 fusion construct that effectively reports the $\mathrm{Ca}^{2+} \mathrm{mi}^{-}$ croenvironment in the vicinity of $\mathrm{C} \times 36$ gap junctions. This tool will be valuable to investigate the dynamic changes in $\mathrm{Ca}^{2+}$ that are responsible for some forms of electrical synapse plasticity. Furthermore, we have discovered that a widely used model system for in vitro studies, the HeLa cell, endogenously expresses glutamate receptors that effectively drive intracellular $\mathrm{Ca}^{2+}$, calmodulin-dependent protein kinase II (CaMKII) signaling. This signaling can be exploited in many types of studies. 
did not require exogenous expression of glutamate receptors, but could be accomplished by endogenously expressed glutamate receptors with pharmacological characteristics reminiscent of NMDA and kainate receptors. Analysis of RNA Sequencing data from HeLa cells confirmed expression of NMDA receptor subunits NR1, NR2C, and NR3B. In summary, Cx36-GCaMP is an effective tool to measure changes in the $\mathrm{Ca}^{2+}$ microenvironment around Cx36 gap junctions. Furthermore, HeLa cells can serve as a model system to study glutamate receptor-driven potentiation of electrical synapses.

Key words: calcium signaling; Connexin 36; electrical synapse; optical imaging; plasticity; tracer coupling

\section{Introduction}

Electrical synapses provide a means to organize neurons into networks from which high-order activity emerges. Plasticity is a fundamental property of electrical synapses, altering the strength of electrical communication between coupled neurons and potentially playing a large role in regulation of network states (Coulon and Landisman, 2017). Electrical synapse plasticity is also a critical element of microcircuit functions. For example, individual auditory afferent terminals that form mixed chemical and electrical synapses onto Mauthner neurons display a high degree of variability in both electrical and chemical synaptic strength (Smith and Pereda, 2003), influencing the effect of any one auditory neuron on Mauthner cell responses. Both components can be modified by activity, resulting in either potentiation or depression of individual elements, with interdependence of chemical and electrical synapse activity (Pereda et al., 2003b; Smith and Pereda, 2003).

In the fish Mauthner neurons, high-frequency stimulation of the afferent nerve results in potentiation of electrical synapses (Yang et al., 1990; Pereda and Faber, 1996). Activity-dependent potentiation of electrical synapses has also been observed in mammalian All amacrine cells (Kothmann et al., 2012) and inferior olive neurons (Turecek et al., 2014). Common among these neural networks is the reliance on activation of NMDA receptors, influx of extracellular $\mathrm{Ca}^{2+}$ and activation of $\mathrm{Ca}^{2+}$, calmodulin-dependent protein kinase II (CaMKII) activity (Pereda et al., 1998, 2003a; Kothmann et al., 2012; Turecek et al., 2014) to potentiate coupling. In retinal All amacrine cells, the potentiation has been

Received October 25, 2019; accepted February 21, 2020; First published March 11, 2020

The authors declare no competing financial interests.

Author contributions: K.B.M. and J.O. designed research; K.B.M., C.K.M., Y.-P.L., Y.-H.L., and J.O. performed research; K.B.M., C.K.M., E.S., and J.O. analyzed data; K.B.M. and J.O. wrote the paper.

This research was supported by the National Institutes of Health Grant R01 EY012857 (J.O.), Core Grant P30 EY028102, and the Louisa Stude Sarofim endowment (J.O.). K.B.M. was supported by Training Grant T32 EY007024.

K. B. Moore's present address: School of Public Health, The University of Texas Health Science Center at Houston, Houston, TX 77030.

Acknowledgements: We thank Dr. Alejandro Vila for assistance with confocal microscopy.

Correspondence should be addressed to John O'Brien at john.obrien@ uth.tmc.edu.

https://doi.org/10.1523/ENEURO.0445-19.2020

Copyright (C) 2020 Moore et al.

This is an open-access article distributed under the terms of the Creative Commons Attribution 4.0 International license, which permits unrestricted use, distribution and reproduction in any medium provided that the original work is properly attributed. demonstrated to result from CaMKII-dependent phosphorylation of Cx36 (Kothmann et al., 2012). $\mathrm{Ca}^{2+}$-dependent depression of electrical synapses has also been reported, depending on NMDA receptors in inferior olive neurons (Mathy et al., 2014) and voltage-dependent $\mathrm{Ca}^{2+}$ channels in thalamic reticular neurons (Sevetson et al., 2017), suggesting that the control of coupling by $\mathrm{Ca}^{2+}$ entry can be subtle.

Because of the central role of $\mathrm{Ca}^{2+}$ signaling in activitydependent modulation of electrical synapse strength, we wished to investigate the relationship between the $\mathrm{Ca}^{2+}$ microenvironment around $\mathrm{C} \times 36$ gap junctions and their functional plasticity. To accomplish this, we developed a Cx36 construct fused to the genetically-encoded $\mathrm{Ca}^{2+}$ biosensor GCaMP3 (Tian et al., 2009). This construct is an effective tool to examine $\mathrm{Ca}^{2+}$ signaling in the context of gap junction functional plasticity.

\section{Materials and Methods}

\section{Clones}

EGFP-N1 vector was obtained from Clontech. A plasmid expressing GCaMP3 in the EGFP-N1 vector was a gift from Loren Looger (Addgene plasmid \#22692; Tian et al., 2009). Mouse Connexin 36 (Cx36) cDNA was a gift from Muayyad Al-Ubaidi (University of Oklahoma; AlUbaidi et al., 2000). NMDA receptor open reading frame clones were a gift from Vasanthi Jayarman (University of Texas Health Science Center at Houston). These included NR1 in pcDNA 3.1 (NCBI accession \#57847), NR2A in pcDNA 3.1 (NCBI accession \#286233), NR2B in pcDNA 3.1 (NCBI accession \#NM_012574), and NR2C in pRK (NCBI accession \#NM_012575.3).

Unless otherwise indicated, restriction enzymes, DNA polymerases and enzymes used for cloning were obtained from New England Biolabs. To produce C-terminal EGFP-tagged Cx36, the mouse $\mathrm{C} \times 36$ cDNA was amplified by PCR using Pfu Ultra DNA polymerase (Agilent) with primers T7 and JOB 284 (all primer sequences are listed in Table 1), the latter of which eliminates the stop codon of Cx36 and adds a Kpnl site in frame with the EGFP-N1 vector. The PCR product was cloned into EcoRI and Kpnl sites of the EGFP-N1 vector by conventional cloning. A Cterminal GCaMP3-tagged Cx36 was produced in a similar fashion using primers T7 and JOB 285, the latter of which eliminates the stop codon of Cx36 and adds a Bcll site. The PCR product was digested with Smal and Bcll and cloned into Afel and Bglll sites of the GCaMP3 vector. Resulting clones were fully sequenced. Cx36-GCaMP is available through Addgene (plasmid \#123604). 
Table 1: Primers used for cloning

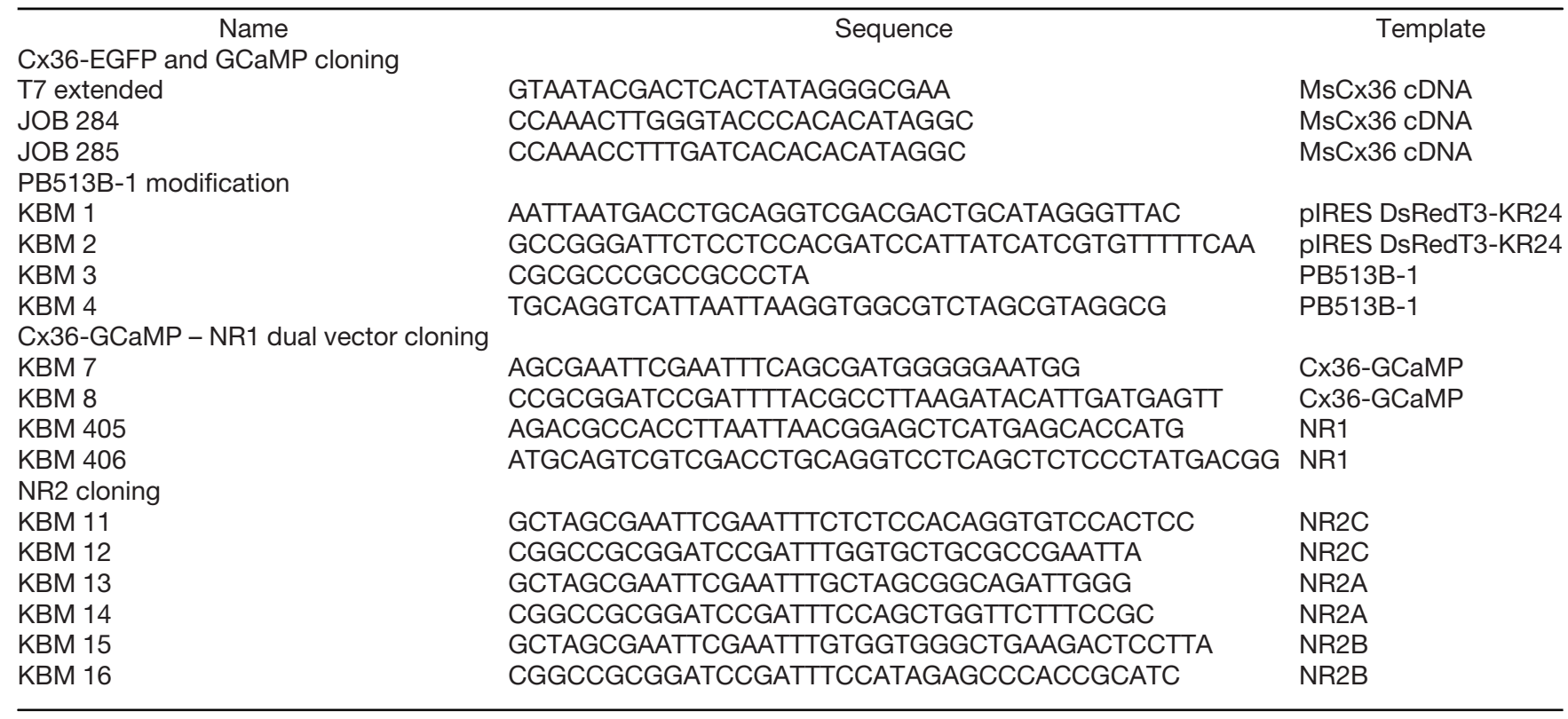

A series of clones was created using the PB513B-1 dual expression vector of the Piggybac Transposon System (System Biosciences LLC). The vector was modified to accept a second user-derived sequence by deleting the GFP open reading frame driven by the EF1a promoter by digestion with Bsu36I and BgmBI and inserting a linker containing $\mathrm{Pacl}$ and Sbfl restriction sites followed by an IRES sequence derived from the vector pIRES DsRedT3-KR24 (Moshiri et al., 2008). The modification was completed by three-way assembly of PCR products amplified with Phusion polymerase using primers KBM 1 and KBM 2 for the IRES and primers KBM 3 and KBM 4 to replace a deleted portion of the EF1a promoter. Cold Fusion cloning mix (System Biosciences) was used for the assembly.

The full open reading frame of Cx36-GCaMP, including the SV40 poly A signal, was amplified by PCR using primers KBM 7 and KBM 8 and inserted into the Swal site following the CMV promoter of the modified PB513 vector using Gibson Assembly. The full coding region of NMDA receptor NR1 was amplified by PCR using primers JOB 405 and JOB 406 and cloned into the Pacl and Sbfl sites following the EF1a promoter of the same construct to generate a dual-expression construct expressing both NR1 and Cx36GCaMP. The NR2 subunits were each cloned into the Swal site of the modified PB513 vector using Gibson Assembly as described above to generate separate single-expression clones. Resulting clones were fully sequenced.

\section{Cell culture and transfection}

Human Embryonic Kidney 293T/17 cells (HEK293, catalog \#CRL-11268; ATCC) used for calcium imaging and immunolabeling experiments were grown in DMEM with sodium pyruvate $+10 \%$ fetal bovine serum (FBS) with penicillin/streptomycin/fungizone. Cells for all experiments were used between passages 4 and 10 relative to the original cell line obtained from ATCC. Cell culture reagents were obtained from Gibco/ThermoFisher. Cells were plated onto 35-mm culture dishes containing coverslips coated with poly-L-lysine and Laminin (Sigma) and grown to 70$80 \%$ confluency. Cells were transiently transfected with Cx36-GCaMP/NR1 and various combinations of NR2 clones in Piggybac vectors, up to a maximum of $4 \mu \mathrm{g}$ of DNA per dish, using GenePorter $\mathrm{H}$ (Genlantis) following the manufacturer's protocol. For all transfections including clones in the modified PB513 vector, Piggybac transposase (PB200, System Biosciences) was included in the transfection mix. Following transfection, cells were grown in MEM (without essential amino acids) + sodium pyruvate, $10 \%$ FBS, penicillin/streptomycin/fungizone and $100 \mu \mathrm{m}$ APV (DL-2-amino-5-phosphonopentanoic acid; Sigma) to prevent toxicity from activation of transfected NMDA receptors. Cells were cultured for $24 \mathrm{~h}$ following transfection, rinsed twice with MEM without APV, and used for experiments.

HeLa cells (catalog \#CCL2; ATCC) used for tracer coupling experiments were grown in MEM with essential amino acids + sodium pyruvate, 10\% FBS and penicillin/ streptomycin/fungizone. Cells for all experiments were used between passages 7 and 20 relative to the original cell line obtained from ATCC. Cells were plated onto tissue culture coated coverslips (ThermoFisher) and grown to $70-80 \%$ confluency. Cells were transiently transfected with clones in pcDNA vectors or Piggybac vectors as were HEK293 cells and cultured for $24 \mathrm{~h}$. Before use in experiments, cells were rinsed twice with MEM.

\section{Immunolabeling}

HEK293 cells transfected with Cx36-GCaMP and NMDA receptor clones were fixed in $4 \%$ formaldehyde in 

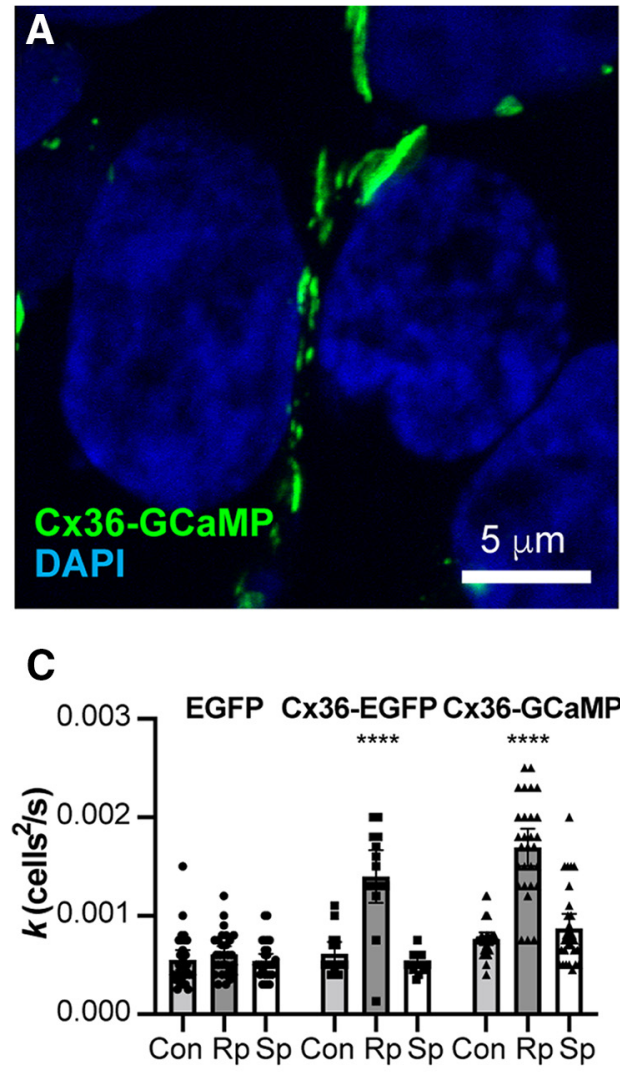
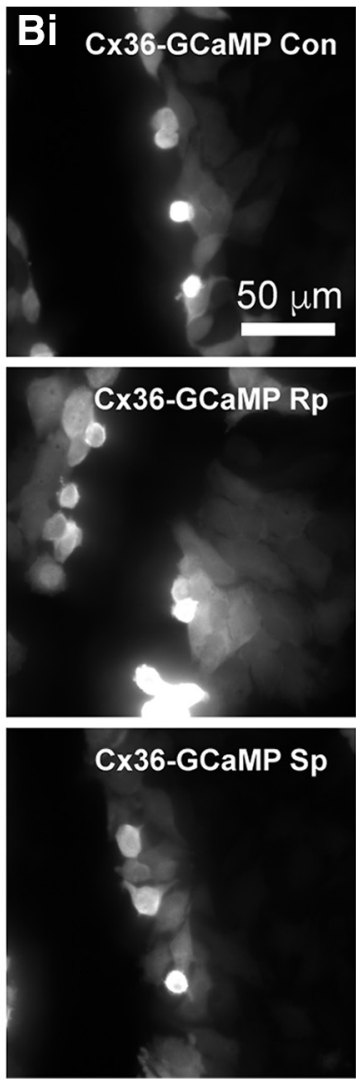

\section{$\mathrm{Bii}$}
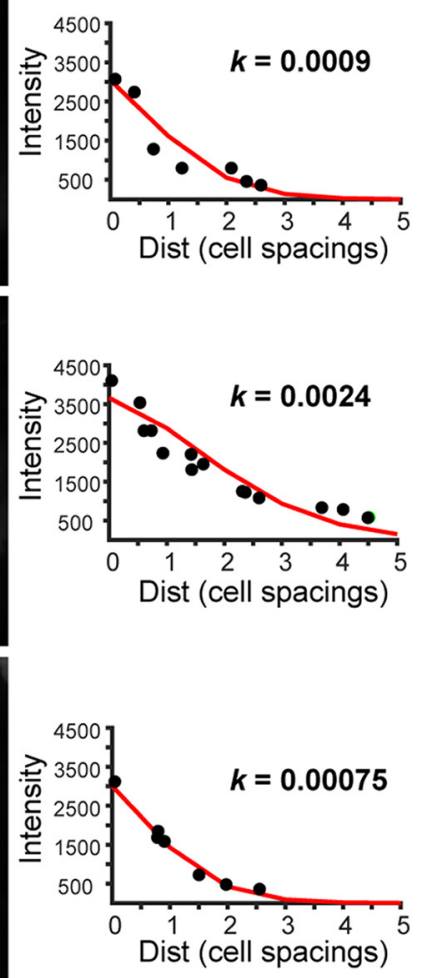

Figure 1. Properties of Cx36-GCaMP. A, Intrinsic fluorescence of Cx36-GCaMP expressed in HEK293 cells. Cx36-GCaMP assembles into gap junctions at cell-cell boundaries. $\boldsymbol{B}$, Tracer coupling measurements of Cx36-GCaMP expressed in HeLa cells. Bi, Neurobiotin loading and diffusion from the scraped edge in cells in control conditions (Con) or treated with $10 \mu \mathrm{m}$ PKA inhibitor (Rp) or $10 \mu \mathrm{M}$ PKA activator (Sp). Bii, Fits of linear compartmental diffusion model to Cy-3 streptavidin fluorescent labeling of Neurobiotin tracer for each of the images shown. Diffusion coefficient $k$ determined from the fit, in cells ${ }^{2} / \mathrm{s}$, is shown on each graph. C, Mean (bars) diffusion coefficients $(k)$ for Neurobiotin tracer coupling in HeLa cells transfected with EGFP, Cx36-EGFP, or Cx36GCaMP. All data are shown for six (EGFP, Cx36-GCaMP) or three (Cx36-EGFP) experiments. Error bars show 95\% confidence limits of the mean; $* * * * p<0.0001$ versus control.

$0.1 \mathrm{M}$ phosphate buffer $(\mathrm{pH} 7.5)$ for $30 \mathrm{~min}$, washed with $0.1 \mathrm{M}$ phosphate buffer, and blocked $1 \mathrm{~h}$ in $5 \%$ normal donkey serum in $0.1 \mathrm{M}$ phosphate buffer, $0.3 \%$ Triton $\mathrm{X}$ 100. Cells were then immunolabeled using polyclonal antibodies for rabbit anti-NR2A (PhosphoSolutions; 1:500 dilution), rabbit anti-NR2B (Biosensis; 1:500 dilution), rabbit anti-NR2C (PhosphoSolutions; 1:500 dilution), and rat anti-NMDA NR1 (UC Davis NeuroMab; 1:500 dilution). Cx36-GCaMP labeling was enhanced using anti-GFP (Jackson ImmunoResearch; 1:500 dilution). Cy3 and Cy5labeled secondary antibodies were purchased from Jackson ImmunoResearch. Imaging was performed on a Zeiss LSM510 Meta confocal microscope using a $40 \times 1$ 1.3 NA objective or a Zeiss LSM780 confocal microscope using a $40 \times / 1.4 \mathrm{NA}$ objective.

\section{Cell perfusion and imaging}

Both HeLa and HEK293 cells were tested in perfusion and imaging experiments. HEK293 cells were superior for this application since most of the transfected Cx36GCaMP was present at gap junctions and these were well organized at vertical cell-cell interfaces (Fig. 1A). HeLa cells displayed a more variable proportion of Cx36GCaMP at cell-cell versus intracellular membrane compartments, making selection of regions of interest for quantification more difficult. To perform the imaging experiments HEK293 cells on 12-mm coverslips transfected with clones for Cx36-GCaMP, NMDA NR1, and NMDA NR2 subunits (NR2A, NR2B, or NR2C) were placed in perfusion chambers (Model RC-25, Warner Instruments) and perfused with cell maintaining solution (CMS) containing $150 \mathrm{~mm} \mathrm{NaCl}, 6.2 \mathrm{~mm} \mathrm{KCl}, 1.2 \mathrm{~mm} \mathrm{NaH}{ }_{2} \mathrm{PO}_{4}, 1.2 \mathrm{~mm}$ $\mathrm{MgSO}_{4}, 2.5 \mathrm{~mm} \mathrm{CaCl}_{2}, 10 \mathrm{~mm}$ glucose, $10 \mathrm{~mm}$ HEPES (pH 7.4), and $1 \mathrm{~mm}$ glycine (CMS + glycine) at $37^{\circ} \mathrm{C}$ using a $\mathrm{VC}^{3}$ 8-channel gravity perfusion system (ALA Scientific Instruments). Cells were imaged using a Zeiss Axiovert 200 microscope with $40 \times / 0.5 \mathrm{NA}$ objective and an ORCA 100 digital camera (Hamamatsu Photonics) using 470BP40 excitation and 535BP40 emission filters. Live images were captured using HClmage software (Hamamatsu) set to record with $4 \times 4$ binning and $0.4-$ to 0.8 -s time intervals. Two to five individual gap junctions on each coverslip were marked as regions of interest for recording. Approximately 20-s baseline measurement was obtained under perfusion with CMS + glycine before switching into solutions 
containing glutamate ( $30 \mu \mathrm{M}, 100 \mu \mathrm{M}$, or $1 \mathrm{~mm})$ for $40 \mathrm{~s}$, followed by return to CMS + glycine. The same perfusion timing was used for applications of $5 \mu \mathrm{M}$ ionomycin (Fisher Chemical) in CMS + glycine. lonomycin experiments also included 5 min pre-incubation with $200 \mathrm{~nm} \mathrm{Na}^{+}-\mathrm{Ca}^{2+}$ exchanger antagonist SEA 0400 (2-[4-[(2,5-difluorophenyl) methoxy]phenoxy]-5-ethoxybenzenamine; R\&D Systems) or $100 \mathrm{~nm}$ SR-ER $\mathrm{Ca}^{2+}$-ATPase antagonist thapsigargin (R\&D Systems) in CMS + glycine, followed by a perfusion experiment with drug in both perfusion solution and ionomycin solution.

Raw fluorescence intensity data from regions of interest were exported from HClmage as tabular data and analyzed in Excel (Microsoft) and Prism (GraphPad). Declining fluorescence intensity of the baseline due to photobleaching was fit with a first-order exponential function or a linear function for each region of interest. This baseline function was used as $F_{0}$ to calculate $\Delta F / F_{0}$ without further correction for background fluorescence, since background regions of interest often showed some changes in fluorescence intensity due to scattered signals from nearby fluorescent $\mathrm{Cx} 36$ GCaMP structures. For each response, we calculated the peak value of $\Delta \mathrm{F} / \mathrm{F}_{0}$ and the integrated area under the response curve, consisting of the sum of $\Delta \mathrm{F} / \mathrm{F}_{0}$ values for each time point contained within the response normalized to $1-$ s time intervals.

\section{Tracer coupling measurements}

Gap junction coupling was analyzed by measuring tracer diffusion of Neurobiotin (Vector Laboratories) loaded into cells by scrape loading (el-Fouly et al., 1987; Opsahl and Rivedal, 2000; Risley et al., 2002). HEK293 cells had unacceptably high background tracer coupling due to the presence of endogenous connexins, so tracer coupling experiments were performed in transiently transfected HeLa cells. Cells were incubated in CMS either alone (control) or containing $10 \mu \mathrm{M}$ protein kinase $\mathrm{A}$ antagonist Rp-8-cpt-cAMPs (Axxora LLC), $10 \mu \mathrm{m}$ protein kinase $A$ agonist Sp-8-cpt-cAMPs (Axxora), $30 \mu \mathrm{M}$ glutamate +1 $\mathrm{mm}$ glycine, or $100 \mu \mathrm{m}$ glutamate $+1 \mathrm{~mm}$ glycine for $5 \mathrm{~min}$. Additional experiments investigating glutamate receptor contribution to tracer coupling employed the 100 $\mu \mathrm{m}$ glutamate $+1 \mathrm{~mm}$ glycine incubation for $5 \mathrm{~min}$ with or without $100 \mathrm{~nm}$ selective kainate receptor antagonist ACET [(S)-1-(2-amino-2-carboxyethyl)-3-(2-carboxy-5phenylthiophene-3-yl-methyl)-5-methylpyrimidine-2,4dione; R\&D Systems], $20 \mu \mathrm{M}$ AMPA/kainate receptor antagonist CNQX (6-cyano-7-nitroquinoxaline-2,3-dione; R\&D Systems), $40 \mu \mathrm{M}$ AMPA and kainate receptor antagonist GYKI 53655 (1-(4-aminophenyl)-3-methylcarbamyl-4methyl-3,4-dihydro-7,8-methylenedioxy-5H-2,3-benzodiazepine hydrochloride; R\&D Systems), or $20 \mu \mathrm{m}$ selective NMDA receptor antagonist (R)-CPP [(R)-3-(2-carboxypiperazin-4-yl)-propyl-1-phosphonic acid; R\&D Systems]. Fresh solutions of appropriate drug were added to each dish with Neurobiotin at a $0.1 \%$ concentration. Cells were scraped with a 26-gauge needle, allowed to incubate $10 \mathrm{~min}$, rinsed three times in CMS, and fixed for $1 \mathrm{~h}$ with $4 \%$ formaldehyde in $0.1 \mathrm{M}$ phosphate buffer. Fixed cells were rinsed briefly in $0.1 \mathrm{M}$ phosphate buffer, permeabilized with PBS,
$0.1 \%$ Triton X-100, 0.1\% Na azide (PBSTA) for $1 \mathrm{~h}$, and labeled with Cy3-strepavidin (1:500; Jackson ImmunoResearch) for $1.5 \mathrm{~h}$. Coverslips were washed with PBSTA for $1 \mathrm{~h}$ and mounted on slides using Vectashield mounting medium (Vector Laboratories) and fluorescently imaged at $40 \times$ magnification.

In each experiment, a minimum of five loaded regions along the scraped edge of the cells were identified for complete single cell loading of Neurobiotin with identifiable transfer of tracer away from the loaded cell as an indicator of a coupled region for measurement. Images were collected using HClmage software and analyzed with SimplePCI (Hamamatsu) and MATLAB (MathWorks) software. Intensity of Neurobiotin/Cy3-streptavidin signal was measured in 2- $\mu \mathrm{m}$ circles, with the brightest regions of individual cells selected. Cell-to-cell distance was measured from center to center of adjacent cells. Tracer diffusion was estimated by fitting data from regions of cells extending out from a loaded cell along the scraped edge of the coverslip (Fig. 1B) using a linear compartmental diffusion model (Zimmerman and Rose, 1985) as implemented for neural networks (Mills and Massey, 1998; O'Brien et al., 2004). In this model we assume the cells are arranged in a linear compartment chain that is connected by $\mathrm{C} \times 36$ gap junctions and may be characterized by a rate-limiting diffusion coefficient $k$. Independent measurements of $k$ were made for each of the five to eight loaded regions examined within a single experiment. Three to six experiments were performed and all values of $k$ used for comparisons.

\section{Gene expression analysis}

In order to better understand the glutamate receptor and connexin gene expression in HeLa cells, we examined RNASeq dataset GSM759888 (https://www.ncbi.nlm.nih. gov/geo/query/acc.cgi?acc=GSM759888) deposited in GEO (Cabili et al., 2011). The bam file of this dataset was mapped against Hg19 human reference genome using Samtools v1.9 (Genome Research Ltd.; http://www.htslib.org; Li et al., 2009) on macOS v10.13/10.14 to generate a bam indexed (bai) file. The files were analyzed using Integrative Genomics Viewer (IGV) v2.4.14 (Broad Institute and Regents of the University of California; https://software.broadinstitute.org/software/igv/ home; Robinson et al., 2011). Each gene of interest was manually searched and an image of read count coverage was exported. IGVtools "count" function was then used to generate the raw read count and normalized read count.

\section{Statistical analyses}

Tracer coupling experiments were performed with control and drug-treated conditions on the same experimental days and batches of cells. Three experiments were performed, except in one case in which a drug treatment did not work, and three additional experiments with control and certain drug treatments were performed. All measurements of $k$ were used from the experiments. A criterion of \pm 3 SDs from the mean was used to exclude outliers among the individual measurements for data analysis. Treatments were compared 
Table 2: Statistical outcomes

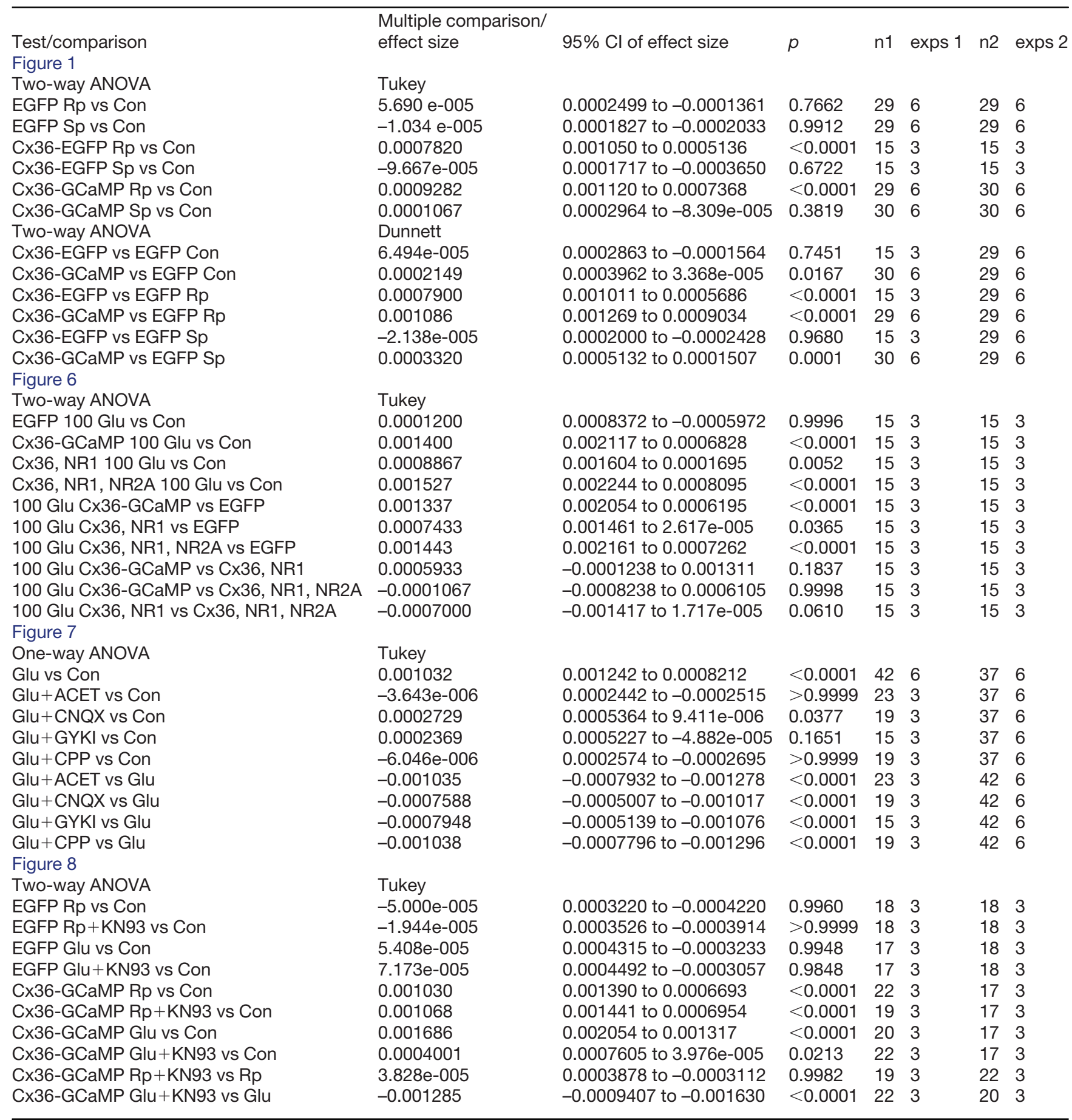

with one-way or two-way ANOVA with appropriate multiple comparison tests. Tukey's multiple comparison tests were used when conditions were compared with more than one other condition; Dunnett's multiple comparisons were used to compare a specific condition in one construct to the same condition in another construct. A summary of all statistical tests performed for this study is presented in Table 2.

\section{Results}

\section{Development of a gap junction calcium sensor}

In order to investigate calcium signaling in the microdomain surrounding $\mathrm{Cx36}$ gap junctions we developed a fusion of mouse Cx36 with GCaMP3 at its cytoplasmic C terminus. Similar to fluorescent protein fusions to the $C$ termini of connexins, this construct, called Cx36-GCaMP, 

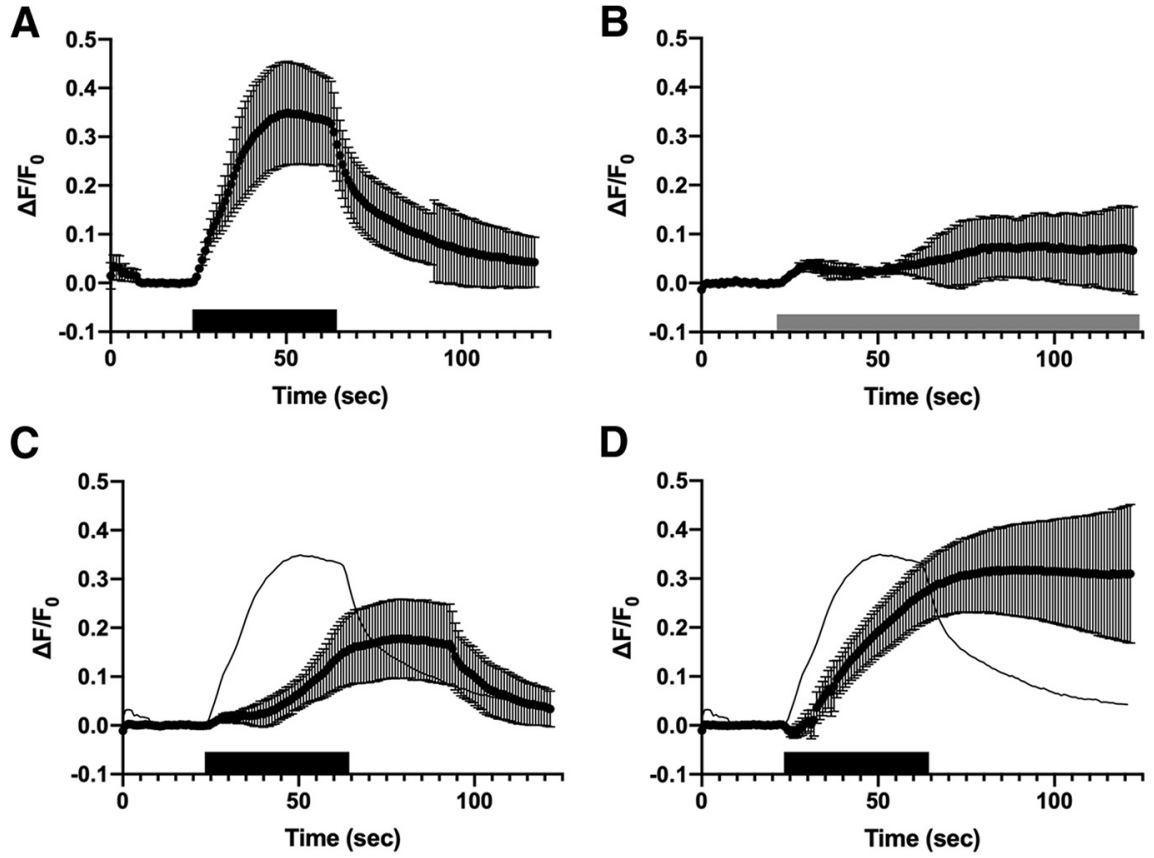

Figure 2. Calcium responses of Cx36-GCaMP. $\boldsymbol{A}$, Fluorescence response to application of $5 \mu \mathrm{m}$ ionomycin for $40 \mathrm{~s}$ (black bar). Data shown are means of 15 gap junctions in three experiments $\pm 95 \%$ confidence limits of the mean. Note that one of three experiments ended at $92 \mathrm{~s}$, so the final $28 \mathrm{~s}$ show 10 gap junctions. B. Fluorescence response to application of $100 \mathrm{~nm}$ thapsigargin (gray bar). Data shown are means of five gap junctions in one experiment $\pm 95 \%$ confidence limits of the mean. $\boldsymbol{C}$, Fluorescence response to application of $5 \mu \mathrm{m}$ ionomycin (black bar) in the presence of $100 \mathrm{~nm}$ thapsigargin. Shown are means of 15 gap junctions in three experiments $\pm 95 \%$ confidence limits of the mean. The mean response to ionomycin in control conditions is shown by the black line for reference. $\boldsymbol{D}$, Fluorescence response to application of $5 \mu \mathrm{m}$ ionomycin (black bar) in the presence of $200 \mathrm{~nm}$ SEA 0400 . Shown are means of 14 gap junctions in three experiments $\pm 95 \%$ confidence limits of the mean. The mean response to ionomycin in control conditions is shown by the black line for reference.

formed gap junctions at cell-cell boundaries when transfected into HEK293 cells (Fig. 1A) or HeLa cells (data not shown). To determine whether Cx36-GCaMP formed functional gap junctions we performed tracer coupling experiments. Because of high background tracer coupling in HEK293 cells due to endogenous connexins, these experiments were performed in transiently-transfected HeLa cells. HeLa cells transfected with control (EGFP) or connexin constructs (Cx36-EGFP or Cx36-GCaMP) were loaded with Neurobiotin along the edge of a scrape (Fig. $1 B i)$ and tracer diffused to connected cells via gap junctions. Fits of Streptavidin-Cy3 fluorescence versus distance from the loaded cell in cell-to-cell spacings with a linear compartmental diffusion model (Fig. 1Bii) allowed calculation of the diffusion coefficient $k$ for Neurobiotin tracer transfer. Figure $1 C$ shows diffusion coefficients measured in cells transfected with Cx36-GCaMP compared with cells transfected with EGFP-N1 (no gap junction control) and Cx36-EGFP. HeLa cells without an added connexin (EGFP control) support some tracer coupling due to the presence of an endogenous connexin. Tracer coupling in Cx36-GCaMP-transfected HeLa cells was significantly increased by inhibition of endogenous protein kinase A activity with $10 \mu \mathrm{M} R \mathrm{Rp}-8$-cpt-cAMPS [two-way ANOVA with Tukey's multiple comparison tests; $p<0.0001$, Con $n=30$ measurements in six experiments,
Rp $n=29$ measurements in six experiments; mean effect size 0.00093 , 95\% confidence interval (Cl) 0.00074 $0.00112)$, similar to the increase in coupling in Cx36EGFP-transfected cells $(p<0.0001$, Con $n=15$ measurements in three experiments, $R p n=15$ measurements in three experiments; mean effect size $0.00078,95 \% \mathrm{Cl}$ $0.00051-0.00105]$. This coupling was significantly greater than in EGFP-transfected cells (two-way ANOVA with Dunnett's multiple comparison tests: Cx36-GCaMP, $p<0.0001, n=29$ measurements in six experiments per construct, mean effect size 0.00109 , 95\% Cl 0.00090 0.00127; Cx36-EGFP, $p<0.0001, n=15$ measurements in three experiments for Cx36-EGFP, $n=29$ measurements in six experiments for EGFP, mean effect size $0.00079,95 \% \mathrm{Cl} 0.00057-0.00101$ ), indicating that Cx36GCaMP forms functional gap junction channels similar to those made by Cx36-EGFP. Stimulation of endogenous protein kinase A activity with $10 \mu \mathrm{M}$ Sp-8-cpt-cAMPS did not significantly change tracer coupling in cells transfected with any of the constructs. None of the treatments significantly affected tracer coupling in EGFP-N1-transfected cells indicating that the endogenous gap junction channels in HeLa cells were not regulated by PKA activity. The pattern of regulation in response to altered PKA activity observed with Cx36-GCaMP is similar to that observed with other Cx36 constructs (Mitropoulou and Bruzzone, 

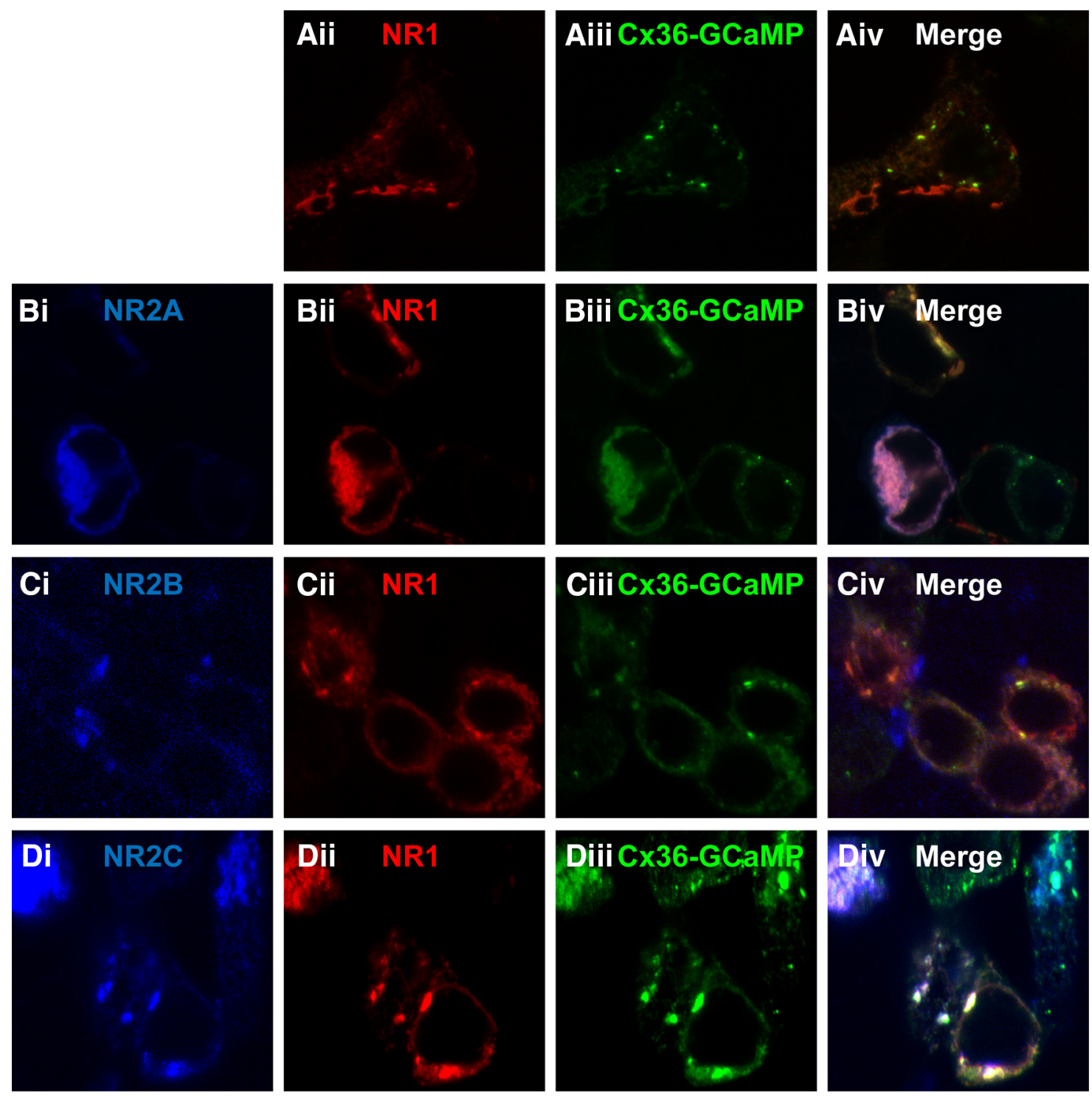

Figure 3. Immunofluorescence labeling of Cx36-GCaMP and NMDA receptors transfected into HEK293 cells. For each transfection combination, Cx36-GCaMP is shown in green, NR1 in red, and NR2x in blue. $\boldsymbol{A}$, Cx36-GCaMP + NR1. B, Cx36-GCaMP + $\mathrm{NR} 1+\mathrm{NR} 2 \mathrm{~A}$. $\boldsymbol{C}, \mathrm{C} \times 36-\mathrm{GCaMP}+\mathrm{NR} 1+\mathrm{NR} 2 \mathrm{~B} . \boldsymbol{D}, \mathrm{Cx} 36-\mathrm{GCaMP}+\mathrm{NR} 1+\mathrm{NR} 2 \mathrm{C}$. Well-formed gap junctions at cell-cell boundaries were used for live imaging experiments, while overexpressing cells with diffusely distributed Cx36-GCaMP were avoided.

2003; Ouyang et al., 2005), indicating that gap junctions made by this construct are regulated in a normal fashion.

When Cx36-GCaMP-transfected HEK293 cells were superfused with CMS containing $2.5 \mathrm{mM} \mathrm{CaCl}_{2}$ and switched to CMS plus $5 \mu \mathrm{m}$ ionomycin, Cx36-GCaMP gap junctions displayed robust increases in fluorescence (Fig. $2 A$; ionomycin application indicated by the black bar) indicating a rise in intracellular calcium in the vicinity of the gap junctions ( $n=15$ gap junctions in three experiments). $\mathrm{Ca}^{2+}$ remained elevated while ionomycin perfusion continued (Fig. 2A), but recovered rapidly on washout in normal CMS. To better understand the etiology of the recovery we investigated the influence of the SR/ER calcium ATPase and the $\mathrm{Na}^{+} / \mathrm{Ca}^{2+}$ exchanger on calcium dynamics. Perfusion of the SR/ER calcium ATPase inhibitor thapsigargin (100 nM; Fig. 2B, gray bar) caused an immediate, small increase in intracellular $\mathrm{Ca}^{2+}$, followed by a more variable delayed rise in intracellular $\mathrm{Ca}^{2+}(n=5$ gap junctions in one experiment). Application of $5 \mu \mathrm{m}$ ionomycin after 5-min pretreatment with thapsigargin (Fig. $2 C ; n=15$ gap junctions in three experiments) resulted in a delayed and reduced relative rise in intracellular $\mathrm{Ca}^{2+}$ with delayed recovery (compare response to the mean ionomycin response in control conditions shown by the black line; ionomycin treatment indicated by the black bar). Note that the intracellular $\mathrm{Ca}^{2+}$ used as the baseline $\mathrm{F}_{0}$ is elevated, so the peak $\mathrm{Ca}^{2+}$ may not be substantially lower than in control conditions. Treatment with the $\mathrm{Na}^{+}$/ $\mathrm{Ca}^{2+}$ exchange inhibitor SEA 0400 (200 nM) also delayed the rise in intracellular $\mathrm{Ca}^{2+}$ and prevented recovery (Fig. $2 D ; n=14$ gap junctions in three experiments). Thus, both $\mathrm{Ca}^{2+}$ stores and plasma membrane $\mathrm{Ca}^{2+}$ handling 
A

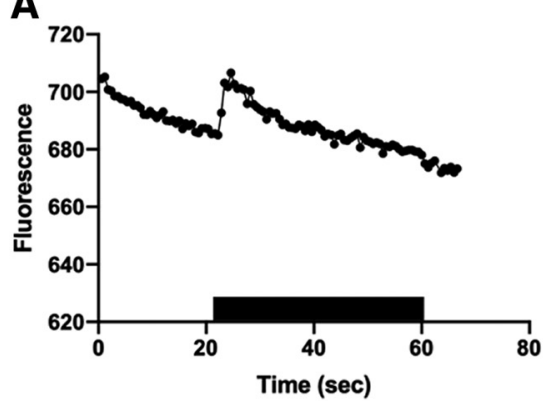

D

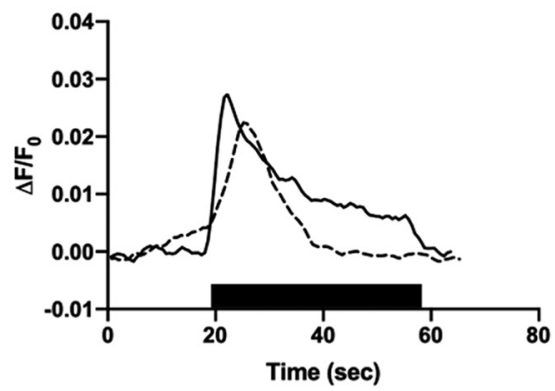

B

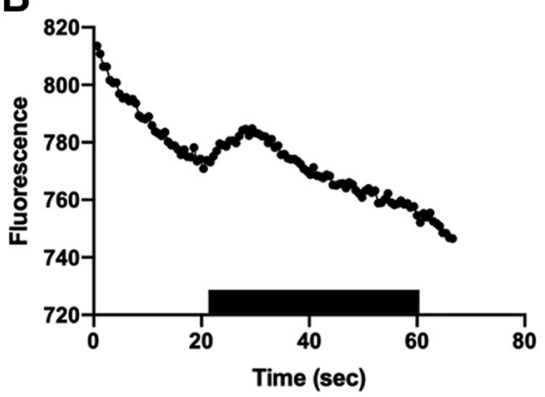

E

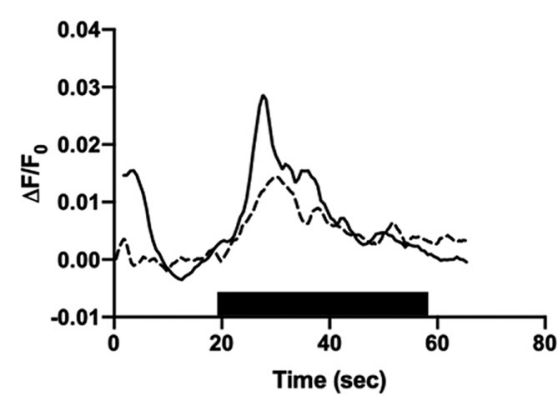

C

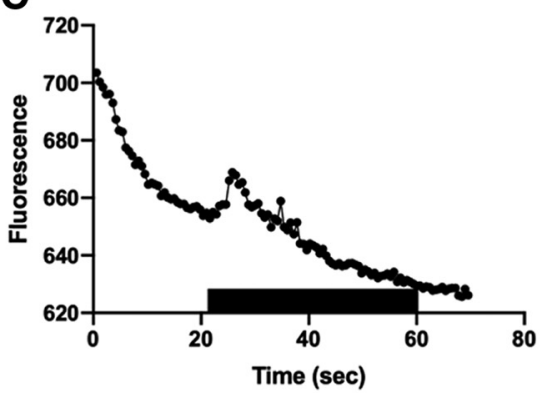

$\mathbf{F}$

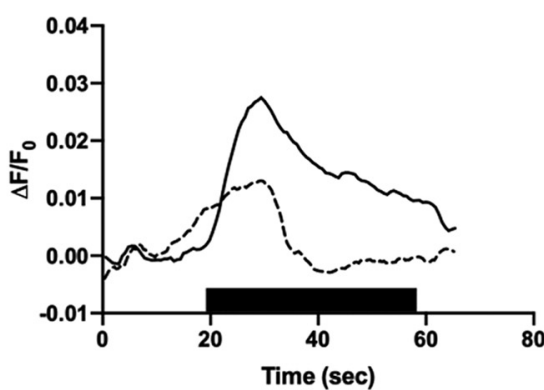

Figure 4. Cx36-GCaMP gap junction responses to glutamate application. Shown in $\boldsymbol{A}-\boldsymbol{C}$ are representative single gap junction raw fluorescence responses to bath application of $100 \mu \mathrm{M}$ glutamate (black bar) in HEK293 cells expressing NMDA receptors containing NR1 and NR2A $(\boldsymbol{A})$, NR2B $(\boldsymbol{B})$, or NR2C $(\boldsymbol{C})$. Baseline subtracted average responses to $30 \mu \mathrm{M}$ (dashed lines) and $100 \mu \mathrm{M}(\mathrm{solid}$ lines) glutamate are shown below in $\boldsymbol{D}-\boldsymbol{F}$. $\boldsymbol{D}, 30 \mu \mathrm{m}$ NR2A, average of eight gap junctions from two experiments; $100 \mu \mathrm{m}$ NR2A, average of five gap junctions from one experiment. $\boldsymbol{E}, 30 \mu \mathrm{M}$ NR2B, average of seven gap junctions from two experiments; $100 \mu \mathrm{M}$ NR2B, average of four gap junctions from one experiment. $\boldsymbol{F}, 30 \mu \mathrm{M}$ NR2C, average of six gap junctions from two experiments; $100 \mu \mathrm{M}$ NR2C, average of 11 gap junctions from three experiments.

significantly influence the kinetics of $\mathrm{Ca}^{2+}$ rise and recovery.

\section{NMDA receptor activation stimulates $\mathrm{Ca}^{2 \pm}$ signals at Cx36-GCaMP gap junctions}

To investigate the coupling of NMDA receptor activation to calcium signals in the vicinity of Cx36 we transfected HEK293 cells with Cx36-GCaMP, NMDA receptor NR1 subunit and one of the NMDA receptor NR2 subunits NR2A, NR2B or NR2C. Figure 3 shows immunostaining of HEK293 cells transfected with Cx36-GCaMP and NR1 (Fig. $3 A$ ), or these two plus NR2A (Fig. 3B), NR2B (Fig. $3 C$ ), or NR2C (Fig. 3D). Expression level did vary among cells, and expression of very high levels of protein in a cell frequently caused delocalization of Cx36-GCaMP away from gap junctions. Only well-formed gap junctions were used for imaging $\mathrm{Ca}^{2+}$ responses, despite quite robust responses observed in cells diffusely expressing Cx36GCaMP.

Triple-transfected cells were superfused with CMS and switched for $40 \mathrm{~s}$ into a solution containing $30 \mu \mathrm{M}, 100 \mu \mathrm{M}$, or $1 \mathrm{~mm}$ glutamate. CMS in all conditions contained $1 \mathrm{~mm}$ glycine to act as a co-agonist for NMDA receptor activation. Figure $4 A-C$ shows example raw single Cx36-GCaMP gap junction responses to $100 \mu \mathrm{m}$ glutamate stimulation. NMDA receptors containing NR2A, NR2B or NR2C all drove transient increases in GCaMP fluorescence, indicative of $\mathrm{Ca}^{2+}$ increases in the microenvironment surrounding the gap junction. Baseline-subtracted average responses from 4 to 11 gap junctions are shown in Figure $4 D-F$. All three types of NMDA receptors drove robust transient increases in local $\mathrm{Ca}^{2+}$ within the first few seconds of glutamate application followed by gradual declines. There were no consistent differences in the kinetics of $\mathrm{Ca}^{2+}$ signals recorded at $\mathrm{Cx36}$ GCaMP gap junctions in response to glutamate stimulation of NMDA receptors containing NR2A, NR2B or NR2C. Figure $5 A, B$ shows concentration-response relationships of the response peak of 8-25 gap junctions in two to eight experiments in cells expressing NR1 and NR2A or NR2B to 30 $\mu \mathrm{M}, 100 \mu \mathrm{M}$, and $1 \mathrm{~mm}$ glutamate. Both NMDA receptor types drove concentration-dependent increases in peak response that were largely similar to each other, with both appearing to saturate between $100 \mu \mathrm{m}$ and $1 \mathrm{~mm}$ glutamate. Because changes in signaling to the gap junction are likely to depend on the total $\mathrm{Ca}^{2+}$ encountered during NMDA receptor responses, we also compared integrated areas under the response curve (Fig. 5C,D) during the course of the responses. These also showed concentration-dependent increases that saturated between $100 \mu \mathrm{m}$ and $1 \mathrm{~mm}$ glutamate.

\section{Glutamate receptor activation increases coupling}

NMDA receptor activation in retinal All amacrine cells (Kothmann et al., 2012) and inferior olive neurons (Turecek et al., 2014) increases Cx36 coupling through $\mathrm{Ca}^{2+}$ and CaMKII-dependent phosphorylation of Cx36. 

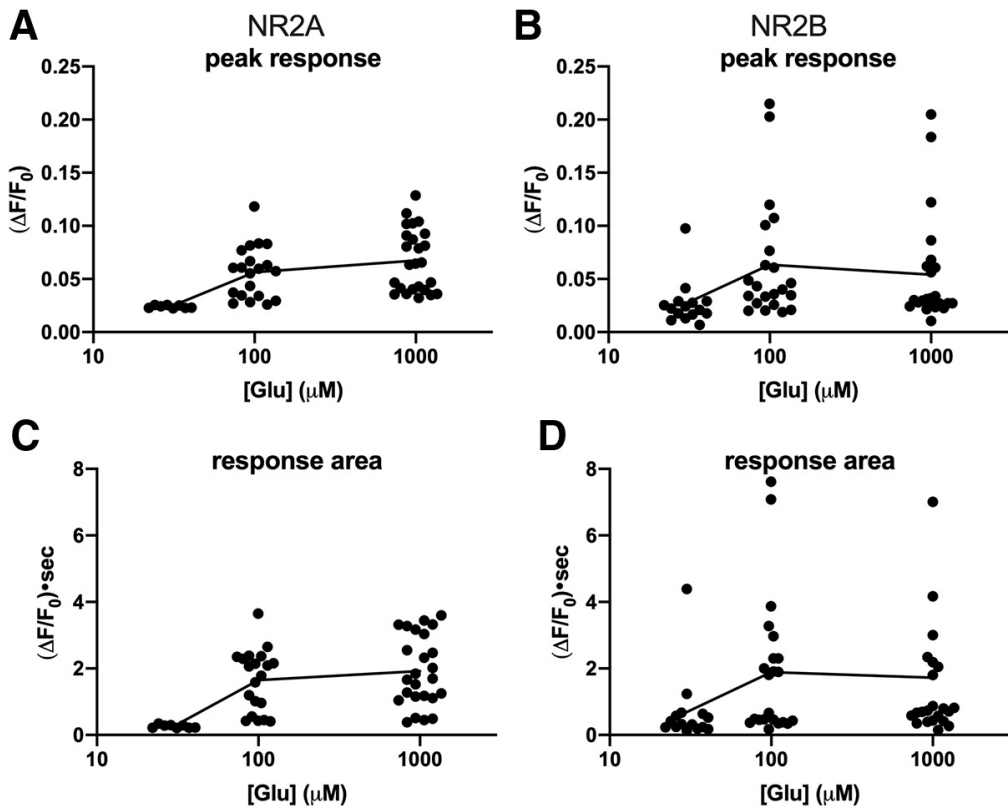

Figure 5. Glutamate concentration-response relationships of Cx36-GCaMP gap junctions in HEK293 cells expressing NR2A-containing and NR2B-containing NMDA receptors. $\boldsymbol{A}, \boldsymbol{B}$, Baseline-subtracted fluorescence peak response for NR2A $(\boldsymbol{A})$ and NR2B-containing $(\boldsymbol{B})$ cells. $\boldsymbol{C}, \boldsymbol{D}$, Integrated area under the response curve for NR2A $(\boldsymbol{C})$ and NR2B-containing $(\boldsymbol{D})$ cells. All data are shown for 8-25 gap junctions from two to eight experiments per condition. The black lines connect the mean responses.

To examine whether NMDA receptor activation can control coupling in Cx36-GCaMP, we examined the effect of 5 -min incubation of $100 \mu \mathrm{M}$ glutamate on tracer coupling in HeLa cells transiently transfected with Cx36-GCaMP, Cx36-GCaMP plus NMDA receptor subunit NR1, or Cx36-GCaMP plus NMDA receptor subunits NR1 and NR2A. EGFP transfection served as a no gap junction control. Figure 6 shows that $100 \mu \mathrm{m}$ glutamate significantly increased coupling in cells expressing intact NMDA receptors consisting of NR1 and NR2A (two-way ANOVA with Tukey's multiple comparison tests; $p<0.0001$, mean effect size $0.00153,95 \% \mathrm{Cl} 0.00081-0.00224 ; n=15$

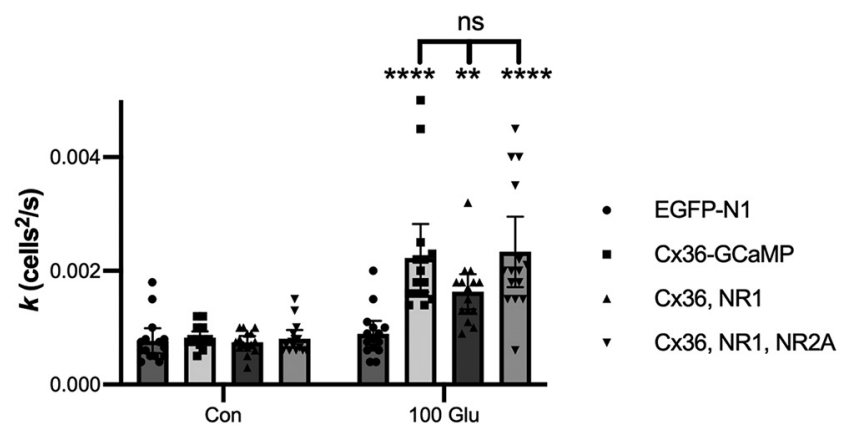

Figure 6. Effects of glutamate application on tracer coupling in HeLa cells expressing EGFP or Cx36-GCaMP with or without added NMDA receptor subunits. The diffusion coefficient $(k)$ for Neurobiotin tracer diffusion is shown for 5 -min preincubation plus 10-min tracer diffusion time in control media (Con) or control media plus $100 \mu \mathrm{m}$ glutamate $(100 \mathrm{Glu})$. All data are shown from three experiments; bars show mean values; error bars show $95 \%$ confidence limits of the mean; $* * p<0.01$, $* * * * p<$ 0.0001 versus same transfection composition in control media. measurements per condition in three experiments). There was no change in coupling in EGFP-transfected controls (two-way ANOVA; $p=0.999 ; n=15$ ). Surprisingly, $100 \mu \mathrm{M}$ glutamate significantly increased coupling when only the NR1 subunit, which does not by itself form a functional NMDA receptor, was transfected with Cx36-GCaMP (two-way ANOVA; $p=0.0052$; mean effect size 0.00089, $95 \% \mathrm{Cl} 0.00017-0.00160 ; n=15)$. Very much to our surprise, HeLa cells transfected only with Cx36-GCaMP also showed a significant increase in coupling with the $100 \mu \mathrm{M}$ glutamate incubation (two-way ANOVA; $p<0.0001$, mean effect size $0.00140,95 \% \mathrm{Cl} 0.00068-0.00212$; $n=15)$. Furthermore, there were no significant differences in the $100 \mu \mathrm{M}$ glutamate condition between cells transfected with Cx36-GCaMP + NR1 and cells transfected with Cx36-GCaMP alone or with Cx36-GCaMP + NR1 + NR2A (two-way ANOVA), and all were significantly greater than the EGFP control (Cx36-GCaMP $p<0.0001$, $n=15$, mean effect size 0.00134 , 95\% Cl $0.00062-$ 0.00205; Cx36-GCaMP + NR1 $p=0.037, n=15$, mean effect size $0.00074,95 \%$ Cl $0.00003-0.00146$; Cx36GCaMP + NR1 + NR2A $p<0.0001, n=15$, mean effect size $0.00144,95 \% \mathrm{Cl} 0.00073-0.00216$ ). These results suggest that HeLa cells express an endogenous glutamate receptor that contributes to signaling that increases coupling in Cx36-GCaMP.

We further characterized the glutamate receptors endogenously expressed in HeLa cells through pharmacological experiments using the effect of 5-min incubation with $100 \mu \mathrm{m}$ glutamate on tracer coupling of Cx36-GCaMPtransfected cells as an assay. Figure 7 shows that several selective and poorly selective glutamate receptor inhibitors prevented the increase in coupling caused by incubation with $100 \mu \mathrm{m}$ glutamate (one-way ANOVA with Tukey's 


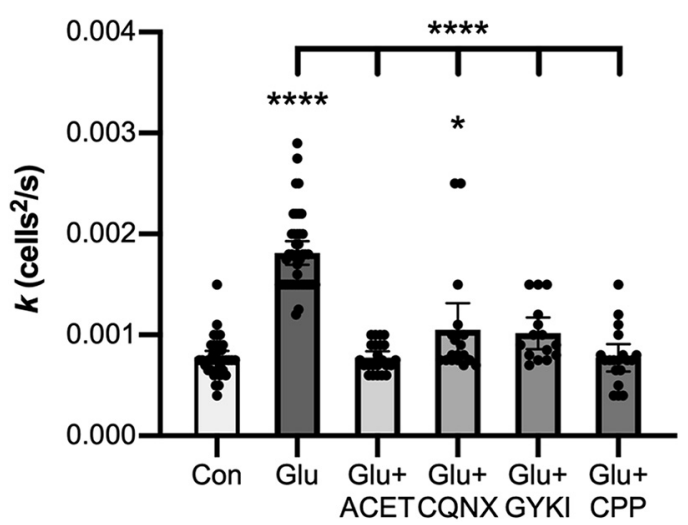

Figure 7. Pharmacological characteristics of endogenous glutamate receptors in HeLa cells expressing Cx36-GCaMP. The diffusion coefficient $(k)$ for Neurobiotin tracer diffusion is shown for 5-min preincubation plus 10-min tracer diffusion time in control media (Con), control media plus $100 \mu \mathrm{m}$ glutamate (Glu), or control media plus $100 \mu \mathrm{m}$ glutamate plus $100 \mathrm{~nm}$ ACET (Glu+ACET), $10 \mu \mathrm{m}$ CNQX (Glu+CNQX), $40 \mu \mathrm{m}$ GYKI 53655 (Glu+GYKI), or $10 \mu \mathrm{M}$ CPP (Glu+CPP). All data are shown from six (Con, Glu) or three experiments; bars show mean values; error bars show $95 \%$ confidence limits of the mean; $* p<0.05$, $* * * * p<0.0001$ versus control condition; comparison of each drug versus $100 \mu \mathrm{m}$ Glu, shown by the bracket, yielded $p<0.0001$ for all.

multiple comparison tests). Each of the following significantly reduced coupling below the $100 \mu \mathrm{m}$ glutamate condition: $100 \mathrm{~nm}$ of the selective kainate receptor antagonist ACET $(p<0.0001$, Glu $n=42$ measurements in six experiments, Glu+ACET $n=23$ measurements in three experiments, mean effect size $-0.00104,95 \% \mathrm{Cl}-0.00079$ to $-0.00128), 10 \mu \mathrm{M}$ of the poorly selective AMPA/kainate receptor antagonist CNQX $(p<0.0001$, Glu $n=42$ measurements in six experiments, Glu+CNQX $n=19$ measurements in three experiments, mean effect size -0.00076 , $95 \% \mathrm{Cl}-0.00050$ to -0.00102$), 40 \mu \mathrm{m}$ of the poorly selective AMPA/kainate receptor antagonist GYKI 53655 $(p<0.0001$, Glu $n=42$ measurements in six experiments, Glu+GYKI $n=15$ measurements in three experiments, mean effect size $-0.00080,95 \% \mathrm{Cl}-0.00051$ to $-0.00108)$, or $10 \mu \mathrm{m}$ of the selective NMDA receptor antagonist CPP $(p<0.0001$, Glu $n=42$ measurements in six experiments, Glu+CPP $n=19$ measurements in three experiments, mean effect size $-0.00104,95 \% \mathrm{Cl}-0.00078$ to -0.00130 ). Of these treatments, only CNQX did not fully block the increase caused by $100 \mu \mathrm{m}$ glutamate, yielding a very slight increase in coupling $(p=0.038$, Con $n=39$ measurements in six experiments, Glu $+\mathrm{CNQX} n=19$ measurements in three experiments, mean effect size $0.00027,95 \%$ $\mathrm{Cl} 0.00001-0.00054)$. This indicates that glutamate receptors in HeLa cells that influence Cx36 coupling have pharmacological characteristics of kainate and NMDA receptors, and may as well have some characteristics of AMPA receptors.

To further investigate the glutamate receptor expression in HeLa cells, we analyzed HeLa RNA Sequence dataset GSM759888 deposited in GEO (Cabili et al., 2011), searching for all of the annotated human ionotropic and metabotropic glutamate receptor genes. Sequence reads were found aligning to a kainate receptor Grik1a antisense transcript, and to transcripts of NMDA receptor subunit genes Grin1 (NR1), Grin2c (NR2C), and Grin3b (NR3B; Table 3). No other glutamate receptor gene transcripts were detected. This further confirms that NMDA receptor genes are expressed in HeLa cells, but does not support the expression of kainate-type receptors, as suggested by the pharmacological properties of the glutamatedriven coupling changes.

We also examined the expression of connexin genes to gain insight into the connexin background that contributes to coupling in HeLa cells (Table 3 ). Substantial numbers of reads mapped to Gja1 (Cx43) and Gjc1 (Cx45) genes, and a smaller number of reads mapped to Gja9 (Cx59)-MYCB readthrough transcript, Gjb3 (Cx31), Gjc2 (Cx47), and Gjd3 (Cx31.9). Thus, there is likely a mixed background of connexins contributing to the coupling detected in control (EGFP-transfected) cells, and as well in those transfected with connexin constructs.

Because glutamate receptor signaling that increases coupling in Cx36 gap junctions depends, at least in part, on CaMKIl activity (Pereda et al., 1998; Kothmann et al., 2012), we examined whether CaMKII was involved in the glutamate-driven increase in Cx36-GCaMP coupling in HeLa cells. Because of the presence of endogenous glutamate receptors that influenced coupling, we did not add additional NMDA receptor subunits. Figure 8 shows tracer coupling of HeLa cells transfected with Cx36-GCaMP or with EGFP. Treatment with $10 \mu \mathrm{m}$ CaMKII inhibitor KN-93 significantly reduced the increase in coupling caused by $100 \mu \mathrm{m}$ glutamate incubation (two-way ANOVA with Tukey's multiple comparison tests: $p<0.0001$, Glu $n=20$ measurements in three experiments, Glu+KN-93 $n=22$ measurements in three experiments, mean effect size -0.00129 , $95 \% \mathrm{Cl}-0.00094$ to -0.00163$)$, although coupling was still slightly enhanced compared with control $(p=0.021$, Con $n=17$ measurements in three experiments, Glu+KN-93 $n=22$ measurements in three experiments, mean effect size $0.00040,95 \% \mathrm{Cl} 0.00041-0.00076$ ). In contrast, while coupling was significantly increased by inhibition of PKA with $10 \mu \mathrm{M}$ Rp-8-cpt-cAMPS $(p<0.0001$, Con $n=17$ measurements in three experiments, $\operatorname{Rp} n=22$ measurements in three experiments, mean effect size 0.00103 , $95 \% \mathrm{Cl} 0.00067-0.00139), 10 \mu \mathrm{M} \mathrm{KN}-93$ did not block this increase $(p=0.998, R p n=22$ measurements in three experiments, $\mathrm{Rp}+\mathrm{KN}-93 n=19$ measurements in three experiments). Thus, the enhancement of coupling caused by activation of endogenous glutamate receptors depended in part on CaMKII, while the coupling revealed by PKA inhibition did not.

\section{Discussion}

Plasticity is a fundamental property of electrical synapses (Curti and O'Brien, 2016) and a great deal of this plasticity results from activity-dependent processes (Pereda et al., 2013; Haas et al., 2016). Calcium signaling has been identified as a critical element of electrical synapse activity-dependent plasticity, controlling protein kinase and phosphatase activities that modify synapse 
Table 3: HeLa gene expression analysis

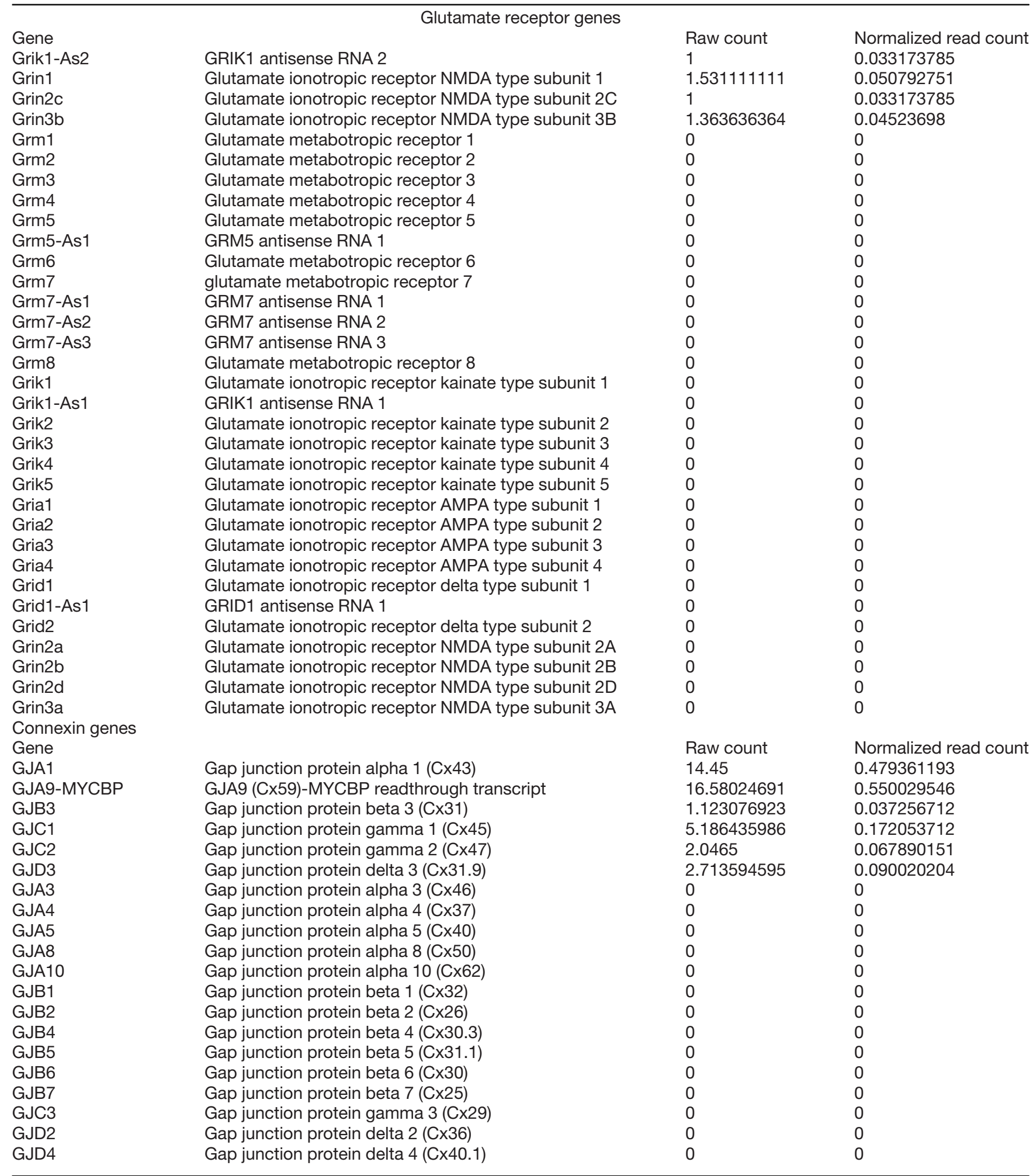

strength (Haas et al., 2016; Coulon and Landisman, 2017; Sevetson et al., 2017; O’Brien, 2019). We have designed a gap junction-localized calcium sensor to study the microenvironment that is most relevant for regulation of electrical synapse plasticity in hopes to further the understanding of dynamic regulation of electrical synapse strength.

Cx36-GCaMP responds robustly to influx of extracellular $\mathrm{Ca}^{2+}$ and reports dynamic changes in its concentration in the immediate vicinity of the gap junction. The 


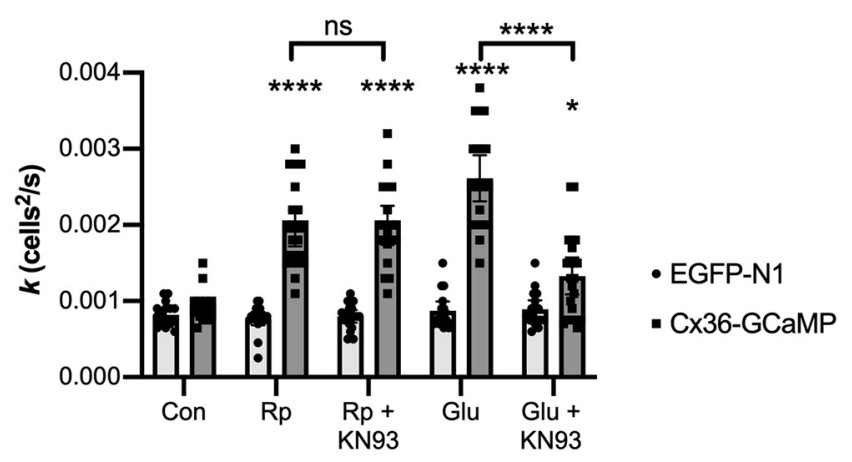

Figure 8. Protein kinase signaling pathways responsible for potentiation of Cx36-GCaMP tracer coupling by $100 \mu \mathrm{m}$ glutamate in HeLa cells. The diffusion coefficient $(k)$ for Neurobiotin tracer diffusion is shown using the same experimental paradigm as in Fig. 6. $\mathrm{Rp}=\mathrm{PKA}$ inhibitor $(10 \mu \mathrm{M}) ; \mathrm{KN}-93=\mathrm{CaMKII}$ inhibitor $(10$ $\mu \mathrm{M}) ; \mathrm{Glu}=100 \mu \mathrm{m}$ glutamate. All data are shown from three experiments; bars show mean values; error bars show $95 \%$ confidence limits of the mean; $* p<0.05, * * * * p<0.0001$; ns = not significant. Symbols above bars represent comparison versus same transfected construct in control media; symbols above brackets represent comparison of the conditions underlying the ends of the brackets.

dynamic nature of the $\mathrm{Ca}^{2+}$ microenvironment is particularly apparent in the response to administration of ionomycin to HEK cells expressing Cx36-GCaMP (Fig. 2). While $\mathrm{Ca}^{2+}$ rises to a peak shortly after onset of ionomycin administration, its level plateaus and is rapidly reduced on washout by cellular processes, which include both extrusion via $\mathrm{Na}^{+}-\mathrm{Ca}^{2+}$ exchangers and sequestration in intracellular compartments such as endoplasmic reticulum and mitochondria. It is likely that the plasma membrane $\mathrm{Ca}^{2+}$-ATPase, which we did not examine, also plays a significant role in extrusion of $\mathrm{Ca}^{2+}$ from the cell. Intracellular stores in the ER play a complex role. Inhibiting the SERCA pump with thapsigargin raised intracellular $\mathrm{Ca}^{2+}$ only a small amount, but potently damped the rate of rise of $\mathrm{Ca}^{2+}$ on ionomycin addition. This suggests that the rise in control conditions includes elements of $\mathrm{Ca}^{2+}$-induced $\mathrm{Ca}^{2+}$ release from the ER stores, or that the elevated cytoplasmic $\mathrm{Ca}^{2+}$ has activated the plasma membrane $\mathrm{Ca}^{2+}$-ATPase or $\mathrm{Na}^{+}-\mathrm{Ca}^{2+}$ exchanger. It is likely that all of these processes are involved in the dynamics of $\mathrm{Ca}^{2+}$ in the vicinity of the $\mathrm{C} \times 36$ gap junctions.

Pertinent to understanding activity-dependent plasticity are the responses of Cx36-GCaMP to glutamate administration in the presence of NMDA receptors. All three types of NMDA receptors tested, those containing NR2A, NR2B, and NR2C, drove qualitatively similar $\mathrm{Ca}^{2+}$ responses at $\mathrm{Cx36-GCaMP}$ gap junctions. Responses peaked in the first few seconds of glutamate administration and often declined in the continued presence of glutamate. The decline no doubt reflects both the desensitization kinetics of the NMDA receptors and the $\mathrm{Ca}^{2+}$ removal processes described above. Despite these processes, $\mathrm{Ca}^{2+}$ remained elevated above the baseline level throughout the duration of the glutamate application for glutamate concentrations of $100 \mu \mathrm{m}$ or higher. This suggests that signaling driven by elevated $\mathrm{Ca}^{2+}$ may be activated continuously when glutamate is present, at least at higher concentrations.

Kothmann et al. (2012) demonstrated that activation of non-synaptic NMDA receptors associated with Cx36 drove an increase in CaMKII activity, resulting in phosphorylation of Cx36 and increased coupling. In an analogous fashion, activation of synaptic NMDA receptors drives potentiation of the electrical synapses in the Mauthner cell mixed synapses through CaMKII activity (Pereda et al., 1998). Phosphorylation of the connexins involved has not been evaluated in that system, but the presence of Cx35 (the fish orthologue of mammalian Cx36) and the highly homologous Cx34.7 at these synapses (Pereda et al., 2003a; Rash et al., 2013) strongly suggests that connexin phosphorylation is the mechanism responsible for activity-dependent potentiation. Such activity-dependent potentiation could be mimicked in the HeLa cell expression system. Tracer coupling supported by $\mathrm{C} \times 36-\mathrm{GCaMP}$ was enhanced by glutamate application in HeLa cells expressing NR2A-containing NMDA receptors. In a surprising twist, tracer coupling was also enhanced by glutamate application in HeLa cells in which no NMDA receptor subunits had been transfected. The increase in coupling depended on CaMKII activity, as would be predicted by a $\mathrm{Ca}^{2+}$-mediated response, suggesting the presence of an endogenous glutamate receptor that supports $\mathrm{Ca}^{2+}$ influx in HeLa cells. Furthermore, the CaMKII activity in HeLa cells was not constitutive. The intervention routinely performed in our group of inhibiting PKA activity with Rp-8-cpt-cAMPS, which appears to increase coupling by reducing PKA-stimulated protein phosphatase $2 \mathrm{~A}$ activity (Kothmann et al., 2009; Yoshikawa et al., 2017), increased coupling in a manner independent of CaMKII activity. Thus, coupling could be increased by constitutive activity of an as yet unidentified protein kinase as well as through glutamateinducible CaMKII activity. The latter pathway provides a useful model system to investigate activity-dependent potentiation of coupling.

In Neuro2A cells, Del Corsso et al. (2012) found CaMKII activation to be responsible for a gradual increase in Cx36-mediated coupling as a result of breaking into a cell pair with patch pipettes. The stimulus for this "run-up" is unclear, although a transient increase in intracellular $\mathrm{Ca}^{2+}$ on break-in was proposed. Thus, in both expression systems (Del Corsso et al., 2012 and this study) and natural systems (Pereda et al., 1998; Kothmann et al., 2012; Turecek et al., 2014), CaMKII activity supports potentiation of coupling. CaMKII is a potent and central regulator of synaptic activity, affecting both AMPA receptor conductance and addition of AMPA receptors to post-synaptic densities (Coultrap and Bayer, 2012). Its role at electrical synapses seems to be comparable. CaMKII phosphorylates Cx36 directly and indeed binds to Cx36 in a manner similar to its binding to NR2B (Alev et al., 2008). In addition, CaMKII is proposed to support the maintenance or insertion of $\mathrm{C} \times 36$ channels, since its inhibition reduced the number of gap junctions on inferior olive neurons (Bazzigaluppi et al., 2017). Thus, CaMKII has attributes that make it likely to be a component of the complex associated with electrical synapses. 
CaMKII is comprised of four isoforms, each with several splice variants, that have distinct cell type distributions, activity and protein binding characteristics, and effects on various aspects of learning and memory (Zalcman et al., 2018). The distributions of the four major isoforms in the context of $\mathrm{C} \times 36$ has been examined in the retina (Tetenborg et al., 2017). Interestingly, the major neuronal isoform $\mathrm{CaMKII} \alpha$ showed virtually no association with $\mathrm{Cx} 36$, while the neuronal isoform CaMKII $\beta$ and the widespread isoform CaMKII $\delta$ were associated with $\mathrm{C} \times 36$ gap junctions in a somewhat cell-type selective manner (Tetenborg et al., 2017, 2019). In All amacrine cells, in which the CaMKIIdriven potentiation of Cx36 coupling depends on Cx36 phosphorylation (Kothmann et al., 2012), CaMKII $\delta$ was the major isoform present (Tetenborg et al., 2017). This isoform supports the highest rate of autophosphorylation of the four (Gaertner et al., 2004), which leads to autonomous activity, albeit considerably lower in the absence of $\mathrm{Ca}^{2+}$-calmodulin binding (Coultrap and Bayer, 2012). In this manner, transient glutamate receptor signaling at Cx36 gap junctions can activate CaMKII to produce sustained phosphorylating activity that potentiates the electrical synapse. In contrast, Bazzigaluppi et al. (2017) have found that knockout of $\mathrm{CaMKII} \beta$, but not $\mathrm{CaMKII} \alpha$, reduced the total number of Cx36 gap junctions in inferior olive neurons, suggesting that the CaMKII $\beta$ isoform is important for maintenance or insertion of $\mathrm{C} \times 36$ in gap junctions. Thus, the means through which CaMKII enhances coupling may differ according to the isoform involved.

Potentiation is not the only outcome of neuronal activity surrounding electrical synapses. In contrast to the NMDA receptor and CaMKII-dependent potentiation of coupling in inferior olive neurons resulting from NMDA application or selective paired-pulse presynaptic stimulation (Turecek et al., 2014), low frequency presynaptic stimulation resulted in lasting depression (Mathy et al., 2014). This depression depended on NMDA receptors, intracellular $\mathrm{Ca}^{2+}$ and CaMKII activity, although it is not clear how the electrical synaptic depression would be achieved. More in keeping with current understanding is the depression of thalamic reticular neuron electrical synapses by burst activity (Sevetson et al., 2017). In these neurons, $\mathrm{Ca}^{2+}$ entry through T-type voltage-gated $\mathrm{Ca}^{2+}$ channels activates calcineurin, with the predicted reduction in Cx36-mediated coupling. The bidirectional modulation of electrical synapse strength by different $\mathrm{Ca}^{2+}$-dependent processes is highly analogous to the differences in synaptic activity that drive long-term potentiation and long-term depression in central glutamatergic synapses. The Cx36GCaMP biosensor we have designed will be useful to investigate these differences.

\section{References}

Al-Ubaidi MR, White TW, Ripps H, Poras I, Avner P, Gomès D, Bruzzone R (2000) Functional properties, developmental regulation, and chromosomal localization of murine connexin36, a gapjunctional protein expressed preferentially in retina and brain. $\mathrm{J}$ Neurosci Res 59:813-826.

Alev C, Urschel S, Sonntag S, Zoidl G, Fort AG, Höher T, Matsubara M, Willecke K, Spray DC, Dermietzel R (2008) The neuronal connexin36 interacts with and is phosphorylated by CaMKII in a way similar to CaMKII interaction with glutamate receptors. Proc Natl Acad Sci USA 105:20964-20969.

Bazzigaluppi P, Isenia SC, Haasdijk ED, Elgersma Y, De Zeeuw Cl, van der Giessen RS, de Jeu MTG (2017) Modulation of murine olivary Connexin 36 gap junctions by PKA and CaMKII. Front Cell Neurosci 11:397.

Cabili MN, Trapnell C, Goff L, Koziol M, Tazon-Vega B, Regev A, Rinn JL (2011) Integrative annotation of human large intergenic noncoding RNAs reveals global properties and specific subclasses. Genes Dev 25:1915-1927.

Coulon P, Landisman CE (2017) The potential role of gap junctional plasticity in the regulation of state. Neuron 93:1275-1295.

Coultrap SJ, Bayer KU (2012) CaMKII regulation in information processing and storage. Trends Neurosci 35:607-618.

Curti S, O'Brien J (2016) Characteristics and plasticity of electrical synaptic transmission. BMC Cell Biol 17:13.

Del Corsso C, Iglesias R, Zoidl G, Dermietzel R, Spray DC (2012) Calmodulin dependent protein kinase increases conductance at gap junctions formed by the neuronal gap junction protein connexin36. Brain Res 1487:69-77.

el-Fouly MH, Trosko JE, Chang CC (1987) Scrape-loading and dye transfer. A rapid and simple technique to study gap junctional intercellular communication. Exp Cell Res 168:422-430.

Gaertner TR, Kolodziej SJ, Wang D, Kobayashi R, Koomen JM, Stoops JK, Waxham MN (2004) Comparative analyses of the three-dimensional structures and enzymatic properties of alpha, beta, gamma and delta isoforms of $\mathrm{Ca}^{2+}$-calmodulin-dependent protein kinase II. J Biol Chem 279:12484-12494.

Haas JS, Greenwald CM, Pereda AE (2016) Activity-dependent plasticity of electrical synapses: increasing evidence for its presence and functional roles in the mammalian brain. BMC Cell Biol 17:14.

Kothmann WW, Massey SC, O'Brien J (2009) Dopamine-stimulated dephosphorylation of connexin 36 mediates All amacrine cell uncoupling. J Neurosci 29:14903-14911.

Kothmann WW, Trexler EB, Whitaker CM, Li W, Massey SC, O'Brien $J$ (2012) Nonsynaptic NMDA receptors mediate activity-dependent plasticity of gap junctional coupling in the All amacrine cell network. J Neurosci 32:6747-6759.

Li H, Handsaker B, Wysoker A, Fennell T, Ruan J, Homer N, Marth G, Abecasis G, Durbin R, Genome Project Data Processing S; 1000 Genome Project Data Processing Subgroup (2009) The sequence alignment/map format and SAMtools. Bioinformatics 25:20782079.

Mathy A, Clark BA, Häusser M (2014) Synaptically induced long-term modulation of electrical coupling in the inferior olive. Neuron 81:1290-1296.

Mills SL, Massey SC (1998) The kinetics of tracer movement through homologous gap junctions in the rabbit retina. Vis Neurosci 15:765-777.

Mitropoulou G, Bruzzone R (2003) Modulation of perch connexin35 hemi-channels by cyclic AMP requires a protein kinase A phosphorylation site. J Neurosci Res 72:147-157.

Moshiri A, Gonzalez E, Tagawa K, Maeda H, Wang M, Frishman LJ, Wang SW (2008) Near complete loss of retinal ganglion cells in the math5/brn3b double knockout elicits severe reductions of other cell types during retinal development. Dev Biol 316:214-227.

O'Brien J (2019) Design principles of electrical synaptic plasticity. Neurosci Lett 695:4-11.

O'Brien J, Nguyen HB, Mills SL (2004) Cone photoreceptors in bass retina use two connexins to mediate electrical coupling. J Neurosci 24:5632-5642.

Opsahl H, Rivedal E (2000) Quantitative determination of gap junction intercellular communication by scrape loading and image analysis. Cell Adhes Commun 7:367-375.

Ouyang X, Winbow VM, Patel LS, Burr GS, Mitchell CK, O'Brien J (2005) Protein kinase A mediates regulation of gap junctions containing connexin35 through a complex pathway. Brain Res Mol Brain Res 135:1-11. 
Pereda A, O'Brien J, Nagy Jl, Bukauskas F, Davidson KGV, Kamasawa N, Yasumura T, Rash JE (2003a) Connexin35 mediates electrical transmission at mixed synapses on Mauthner cells. J Neurosci 23:7489-7503.

Pereda A, O'Brien J, Nagy JI, Smith M, Bukauskas F, Davidson KGV, Kamasawa N, Yasumura T, Rash JE (2003b) Short-range functional interaction between connexin35 and neighboring chemical synapses. Cell Commun Adhes 10:419-423.

Pereda AE, Faber DS (1996) Activity-dependent short-term enhancement of intercellular coupling. J Neurosci 16:983-992.

Pereda AE, Bell TD, Chang BH, Czernik AJ, Nairn AC, Soderling TR, Faber DS (1998) Ca2+/calmodulin-dependent kinase II mediates simultaneous enhancement of gap-junctional conductance and glutamatergic transmission. Proc Natl Acad Sci USA 95:1327213277.

Pereda AE, Curti S, Hoge G, Cachope R, Flores CE, Rash JE (2013) Gap junction-mediated electrical transmission: regulatory mechanisms and plasticity. Biochim Biophys Acta 1828:134-146.

Rash JE, Curti S, Vanderpool KG, Kamasawa N, Nannapaneni S, Palacios-Prado N, Flores CE, Yasumura T, O'Brien J, Lynn BD, Bukauskas FF, Nagy JI, Pereda AE (2013) Molecular and functional asymmetry at a vertebrate electrical synapse. Neuron 79:957-969.

Risley MS, Tan IP, Farrell J (2002) Gap junctions with varied permeability properties establish cell-type specific communication pathways in the rat seminiferous epithelium. Biol Reprod 67:945-952.

Robinson JT, Thorvaldsdóttir H, Winckler W, Guttman M, Lander ES, Getz G, Mesirov JP (2011) Integrative genomics viewer. Nat Biotechnol 29:24-26.

Sevetson J, Fittro S, Heckman E, Haas JS (2017) A calcium-dependent pathway underlies activity-dependent plasticity of electrical synapses in the thalamic reticular nucleus. J Physiol 595:44174430.
Smith M, Pereda AE (2003) Chemical synaptic activity modulates nearby electrical synapses. Proc Natl Acad Sci USA 100:48494854.

Tetenborg S, Yadav SC, Hormuzdi SG, Monyer H, Janssen-Bienhold $U$, Dedek K (2017) Differential distribution of retinal $\mathrm{Ca}^{(2+)} /$ calmodulin-dependent kinase II (CaMKII) isoforms indicates CaMKII- $\beta$ and $-\delta$ as specific elements of electrical synapses made of Connexin36 (Cx36). Front Mol Neurosci 10:425.

Tetenborg S, Yadav SC, Brüggen B, Zoidl GR, Hormuzdi SG, Monyer H, van Woerden GM, Janssen-Bienhold U, Dedek K (2019) Localization of retinal $\mathrm{Ca}^{2+} /$ calmodulin-dependent kinase II- $\beta$ $(\mathrm{CaMKII}-\beta)$ at bipolar cell gap junctions and cross-reactivity of a monoclonal anti-CaMKII- $\beta$ antibody with Connexin36. Front Mol Neurosci 12:206.

Tian L, Hires SA, Mao T, Huber D, Chiappe ME, Chalasani SH, Petreanu L, Akerboom J, McKinney SA, Schreiter ER, Bargmann Cl, Jayaraman V, Svoboda K, Looger LL (2009) Imaging neural activity in worms, flies and mice with improved GCaMP calcium indicators. Nat Methods 6:875-881.

Turecek J, Yuen GS, Han VZ, Zeng XH, Bayer KU, Welsh JP (2014) NMDA receptor activation strengthens weak electrical coupling in mammalian brain. Neuron 81:1375-1388.

Yang XD, Korn H, Faber DS (1990) Long-term potentiation of electrotonic coupling at mixed synapses. Nature 348:542-545.

Yoshikawa S, Vila A, Segelken J, Lin YP, Mitchell CK, Nguyen D, O'Brien J (2017) Zebrafish connexin 79.8 (Gja8a): a lens connexin used as an electrical synapse in some neurons. Dev Neurobiol 77:548-561.

Zalcman G, Federman N, Romano A (2018) CaMKII isoforms in learning and memory: localization and Function. Front Mol Neurosci 11:445.

Zimmerman AL, Rose B (1985) Permeability properties of cell-to-cell channels: kinetics of fluorescent tracer diffusion through a cell junction. J Membr Biol 84:269-283. 